\title{
Morphology, anatomy and histology of Doto uva Marcus, 1955 (Opistho- branchia: Nudibranchia) from the Chilean coast
}

\author{
María Angélica Fischer ${ }^{1}$, Gerard van der Velde ${ }^{2,3}$, Eric W. Roubos ${ }^{1}$ \\ ${ }^{1}$ Department of Cellular Animal Physiology, Institute for Neuroscience and ${ }^{2}$ Department of Animal Ecology \\ and Ecophysiology, Institute for Water and Wetland Research, Faculty of Science, Radboud University Nij- \\ megen, Toernooiveld 1, 6525 ED Nijmegen, The Netherlands; ${ }^{3}$ National Museum of Natural History Naturalis, \\ P.O. Box 9517, 2300 RA Leiden, The Netherlands
}

Key words: Opisthobranchia, Nudibranchia, Doto, Histology, Morphology, Chilean coast

\begin{abstract}
Doto uva Marcus, 1955 is a nudibranch species recorded from the Brazilian and Chilean coast. In spite of its wide distribution, D. uva has been described only superficially, mainly as to the pattern of its coloration, external morphology, radular teeth and reproductive system. Here we substantially extend this description, paying special attention to the morphology, anatomy and histology of the digestive and reproductive system. Furthermore, new data on the morphology of the central nervous system and its cell types are given, and finally, the egg mass is described. On the basis of these data, we consider the Doto specimens described from Chile conspecific with those from Brazil.
\end{abstract}

\section{Contents}

Introduction ............................................................................................. 145

Material and Methods ........................................................................ 146

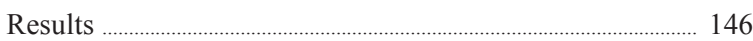

Systematics ................................................................................... 146

External morphology ..................................................................... 146

Coloration ................................................................................... 148

Digestive and excretory system …………………………........ 148

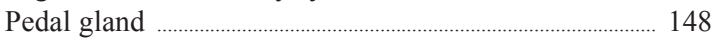

Reproductive system ................................................................... 148

Central nervous system and sensory organs ...................... 151

Egg mass ....................................................................................... 152

Discussion ……………………………………………………………..... 152

Doto uva from the Chilean coast ............................................ 153

Comparison of Doto uva from Chile with Doto uva

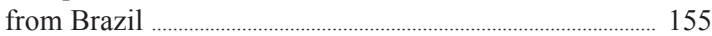

Acknowledgements ........................................................................... 158

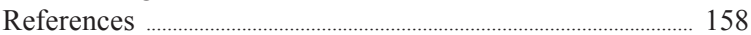

\section{Introduction}

The genus Doto Oken, 1815 is one of the less known nudibranch genera. According to Odhner (1936),
Marcus (1961), Schmekel and Portmann (1982), McDonald (1983) and Thompson and Brown (1984), the main characters to diagnose the genus Doto are as follows: body limaciform and highly arched; foot narrow, linear, rounded anteriorly, tapering posteriorly to a short, blunt tail; anterior foot corners rounded and not protruding; cerata without cnidosac, bulbous, tuberculate, rather club-shaped, and arranged in dorso-lateral rows on each side, the large anterior ceratal pairs bearing a plume-like "gill" on the inner surfaces; round frontal veil instead of oral tentacles; rhinophores smooth and bluntly tapered, retracted into calyciform sheaths; anus and nephroproct in latero-dorsal position; small jaws with smooth masticatory border; radula uniseriate, with numerous, somewhat asymmetrical teeth with few denticles; penis unarmed.

At the Pacific coasts ca. 11 species of the genus Doto have been described, distributed over North America, South America and Japan (O'Donoghue, 1921; Baba, 1938, 1949, 1955, 1971; Marcus, 1955, 1957, 1959, 1961; MacFarland, 1966; Marcus and Marcus, 1967; Gosliner and Williams, 1970; Farmer, 1980; McDonald, 1983; Behrens, 1991; Schrödl, 1996, 2003). The characters to distinguish these species have been mainly morphological, whereas Lemche (1976) took a wider approach including not only body colour pattern but also food preference and shape of spawn. Nevertheless, descriptions of the various Doto species are rather fragmentary and sometimes inconsistent (Baba, 1955, 1971), indicating the poor knowledge about this genus.

The present study concerns a detailed description of D. uva Marcus, 1955. Originally, Marcus (1955) described and Marcus (1957) redescribed this species 
from the coast of Sao Paulo, Brazil, and later Marcus (1959) recorded it at the southern Chilean coast, in Ancud, Chiloe Island. More recently, Schrödl (1996, 2003) recorded D. uva in Coliumo (central Chilean coast) and Schrödl et al. (2005) from the southern Chilean Comau Fjord, whereas Fischer and Cervera (2005) considerably extended its known geographical distribution range, to Tongoy, Coquimbo and Tocopilla (northern Chilean coast). Although relatively widely distributed and frequently found, $D$. uva has been described only superficially, and the data available mainly concern its general coloration, external morphology, and the gross anatomy of the radula and of the reproductive system. Here we present a detailed study on the morphology, anatomy and histology of D. uva from the Chilean coast, with special attention to the reproductive, digestive and central nervous system (CNS), contributing in this way to the knowledge of the genus Doto in general and of Doto uva in particular.

\section{Materials and methods}

The following specimens of Doto uva were studied. (1) 25 specimens, deposited as number MZUSP25275 in the Museo Zoologico Universidad de Sao Paulo Brazil, collected at Isla San Sebastiao, Sao Paulo, Brazil (Leg. L. Fornelis); (2) 1 specimen, deposited as number SMNH-1516 in the Zoological Museum in Stockholm (Sweden), collected during the Lund Expedition 1948-1949, station number M17, on December 14, 1948 at Golfo de Ancud,

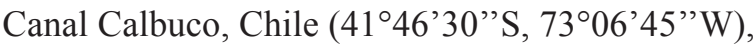
preserved length $4.5 \mathrm{~mm}$ (Table 1); (3) 1 specimen, deposited as number SSUC-3038 in the 'Colección de Flora y Fauna Profesor Patricio Sanchez Reyes, Pontificia Universidad Católica de Chile', collected at Punta Blanca, Tocopilla, Chile $\left(22^{\circ} 04^{\prime} \mathrm{S}\right.$; $70^{\circ} 12^{\prime} \mathrm{W}$ ), preserved length $5 \mathrm{~mm}$; (4) 6 specimens, collected on March 5, 1992, in Bay La Herradura, Coquimbo, Chile (29 $\left.58^{\prime} \mathrm{S} ; 71^{\circ} 22^{\prime} \mathrm{W}\right)$ at a depth of 5 metres, preserved lengths 3.0-5.0 mm, and (5) 3 specimens, collected on January 4, 1995 in Bay Tongoy, Coquimbo, Chile ( $30^{\circ} 15^{\prime} \mathrm{S}$; $\left.71^{\circ} 30^{\prime} \mathrm{W}\right)$, at a depth of 3.5 metres, preserved lengths of $4.7-6.0 \mathrm{~mm}$ (Leg. M.A. Fischer).

Specimens from (1) to (3) were only observed as to their external morphology. Specimens from (4) and (5) were observed alive for their morphology, and subsequently refrigerated at $4{ }^{\circ} \mathrm{C}$ for $6 \mathrm{hrs}$, and fixed in 4\% formaldehyde in seawater, for 20 days, and then stored in $70 \%$ ethanol. Four specimens from the localities La Herradura and Tongoy were dissected to study their anatomy. From two of these specimens the buccal mass was dissected and subsequently immersed into $10 \% \mathrm{NaOH}$ until the tissue surrounding the jaws and radula had been dissolved, and then the material was observed in toto under the light microscope. One complete specimen of Tongoy was dehydrated in a graded ethanol series, embedded in hydroxy-ethylmethacrylate and cut into $2.5 \mu \mathrm{m}$ serial sections on an Leica Reichert Autocut microtome (Leica Microsystems, Wetzlar, Germany) for histological observation. Sections were stained with toluidine-blue to identify structures on the basis of metachromasia.

\section{Results}

Systematics

The systematic position of $D$. uva is as follows. CLADOBRANCHIA Willan and Morton, 1984 DENDRONOTOIDEA Sars, 1878

Dotidae Gray, 1853

Doto Oken, 1815 (type species: Doris coronata Gmelin, 1791) I.C.Z.N opinion No 697

Doto uva Marcus, 1955

\section{External morphology}

The body of $D$. uva is limaciform and arched, being highest in its mediodorsal area (Figs. 1A, B, 2A, B). The head shows a pair of smooth rhinophores with blunt apices, surrounded by rhinophoral sheaths that reach a third of the total length of the rhinophores in living specimens (Figs. 1A, B, 2AE). A veil without projections is present in front of the rhinophores. The sheaths are frontally tapered and protrude more or less prominently depending on the specimen (Fig. 1A, C, D-F; 2C-E).

On each side of the body, up to 7 cerata occur (Table 1; Figs. 1A, F, 2A, B). Each ceras is connected to the body by a short peduncle (Fig. 2F), has 4-6 rings of 4-6 semiglobular tubercles and one tubercle at the top (Fig. 2F, G). Cerata are club-shaped 

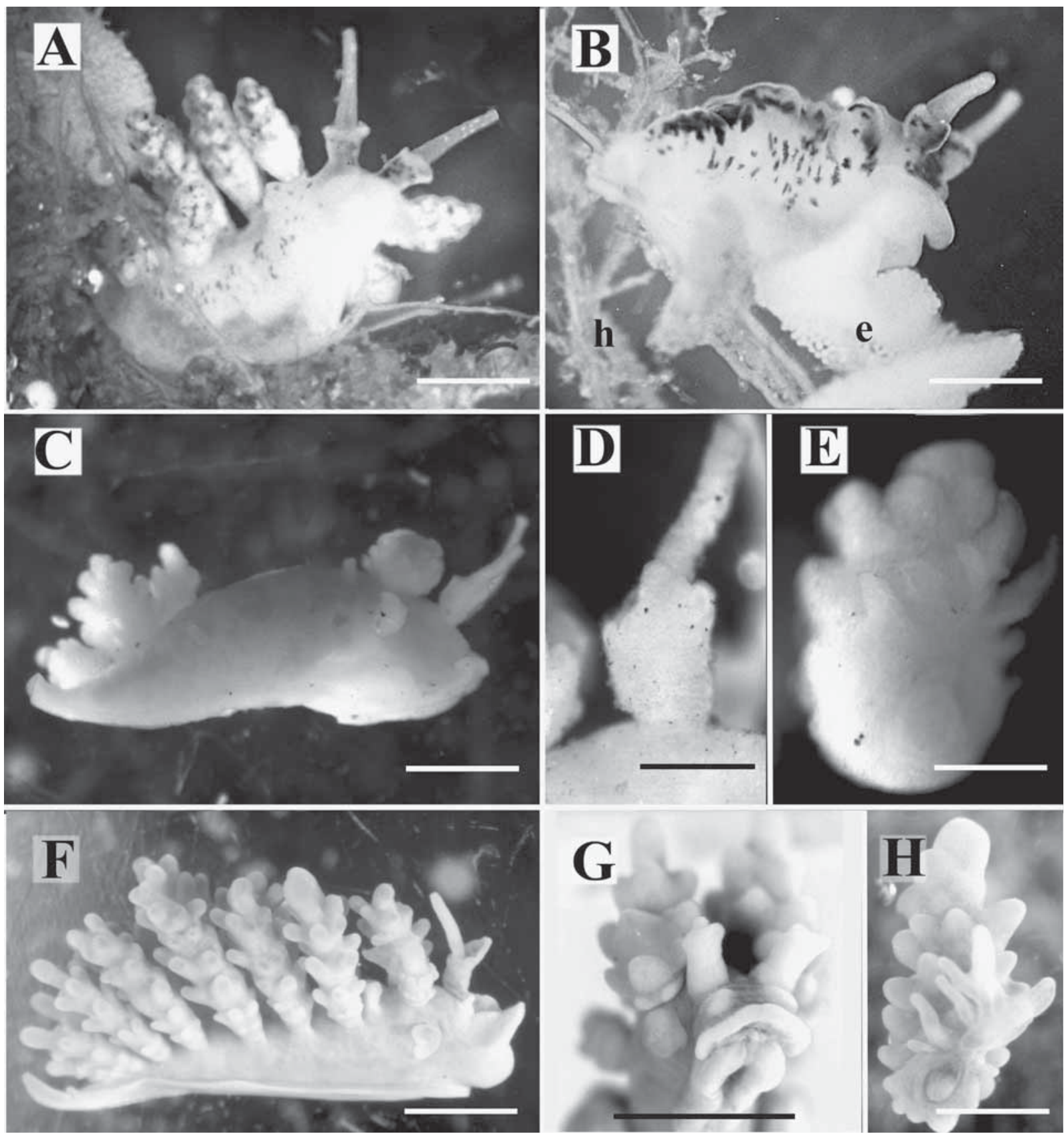

Fig. 1. A-B external morphology of D. uva Marcus, 1955 from the Chilean coast (collected by M.A. Fischer) A: Living specimen. B: Living specimen, with all cerata released, and with egg mass (e) deposited on hydroid colonies (h). C-E preserved specimen of $D$. uva from the Chilean coast described by Marcus (1959). C: Right lateral view. D: detail of the rhinophoral sheath. E. Ceras, interior view with detail of the pseudobranchia. F-H, preserved specimen of D. uva from the Brazilian coast. F: Right lateral view. G: Frontal view. $\mathrm{H}$ : Ceras, interior view with detail of the pseudobranchia. Scale bars: $1 \mathrm{~mm}(\mathrm{~A}, \mathrm{~B}, \mathrm{C}, \mathrm{F}, \mathrm{G}) ; 0.5 \mathrm{~mm}(\mathrm{D}, \mathrm{E}, \mathrm{H})$.

with tubercles that decrease in size towards the peduncle. At the inner side of a ceras a pseudobranch is situated with 3-4 ramifications of varying lengths (Fig. 2F, G). Cerata can be autotomized from the peduncle (Fig. 1B, C) in response to a threatening challenge. In some specimens, small, regenerating cerata were observed.

The genital orifice is located at the right side of 
the body, below the first ceras, and protrudes as a cylindrical genital papilla (Figs. 1C, F, 2B). At this side, between the first and second cerata, the anus and nephroproct form together a prominent papilla (Fig. 2A, B). The voluminous pericardium (Fig. 2A, B) starts just behind the first ceras. The tail is short and undulated. The foot is narrow and extends slightly from under the mantle (Fig. $2 \mathrm{H}$ ).

\section{Coloration}

The coloration patterns of living and preserved animals are nearly the same. The body is transparent yellow to creamish white, with dark-brown dots dispersed over the dorsum, the lateral flanks, the cephalic rhinophoral sheaths, the cerata and the anal papilla (Figs. 1,2). The rhinophores are covered with small white dots from halfway till the apex. In addition, they show small white dots at the sheath borders.

The digestive gland is clearly visible through the transparent body wall, as a thick, darkish brown band (Figs. 1B). In specimens from La Herradura the digestive gland is nearly black but in specimens from Tongoy it is grayish. The gland starts behind the rhinophores and ends in front of the tail. The tubercles of the cerata are covered with dark-brown dots but have a black-pigmented subapical ring and a white, transparent apex. Pseudobranchia are rather dark at the rachis and light at the ramifications (Fig. $2 \mathrm{~F})$. The black pigment of the eyes is visible at the basis of the transparent rhinophores.

\section{Digestive and excretory system}

Anatomy (Fig. 3). The masticatory apparatus was studied in detail in two specimens (preserved length: $4 \mathrm{~mm}$ ). The very thin jaws measure $1.7 \mathrm{~mm}$ in length and have smooth masticatory processes (Fig. 3A). The uniseriate radula is small, about $0.75 \mathrm{~mm}$ in length, and has a teeth formula $61-63 \times(0.0 .1 .0 .0)$. The asymmetrically arched teeth are horseshoeshaped, with up to 5 lateral denticles and one central cusp. The number of denticles, however, varies within a given radula, and some teeth may show as few as 2 denticles. The largest tooth measured 14 $\mu \mathrm{m}$ and the smallest $11 \mu \mathrm{m}$ (Fig. 3B, C).

Histology. The salivary gland consists of two main parts. The distal part, located just in front of the buccal bulb, is formed by numerous glandular cells that are violet-stained and have a small, round and deep-blue nucleus (T1). It opens into the oesophagus via a thin duct. The proximal part has a globular appearance and reveals three different cell types as judged from their size, shape and staining (Fig. 4A). The first type (T1) is similar to that of the distal part of the gland. The second type consists of mediumsized cells with a small, blue nucleus and a deep-blue nucleolus (T2), and the third type is formed by very large cells that reveal a granulated cytoplasm and a large, central, blue nucleus with a deep-blue nucleolus (T3). Finally, around the globular part, just outside the gland, we counted up to twelve giant cells (mean diameter ca. $150 \mu \mathrm{m})$. They are blue, with a large nucleus and several nucleoli (Fig. 4A, B).

Generally, the stomach epithelium is only slightly folded but in the direction of the intestine folds become deeper. Inside the cerata the digestive gland is highly folded. In the epidermis of the cerata intensely stained glandular cells occur (Fig. 4C). The kidney has a thin and highly vacuolated epithelium (Fig. 4E) and is connected to the pericardium by a piriform syrinx (Fig. 4D). The anus is located close to the thin nephroproct, and shows a folded and strongly ciliated epithelium (Fig. 4E).

\section{Pedal gland}

Histology. The pedal gland (Fig. 4F) lies concentrated in the anterior periphery of the foot, in the lips and around the oral opening. It is constituted of numerous semispherical follicles with deep-rosestaining cells that have a strongly granulated cytoplasm and a dark-blue, centrally located nucleus.

\section{Reproductive system}

Anatomy (Fig. 5). The anatomy of the reproductive system was reconstructed using serial sections. The ovotestis appears like a granulated, compact mass, lying over the kidney and occupying nearly one-third of the visceral cavity. It is connected with the ampulla by a short hermaphroditic duct. The ampulla is thick, refringent and globular-shaped. The short, postampullar spermoviduct splits into a male and a female part. Immediately after the bifurcation of the spermoviduct the male duct forms a sausage-shaped prostate gland and then runs into the muscular penial 


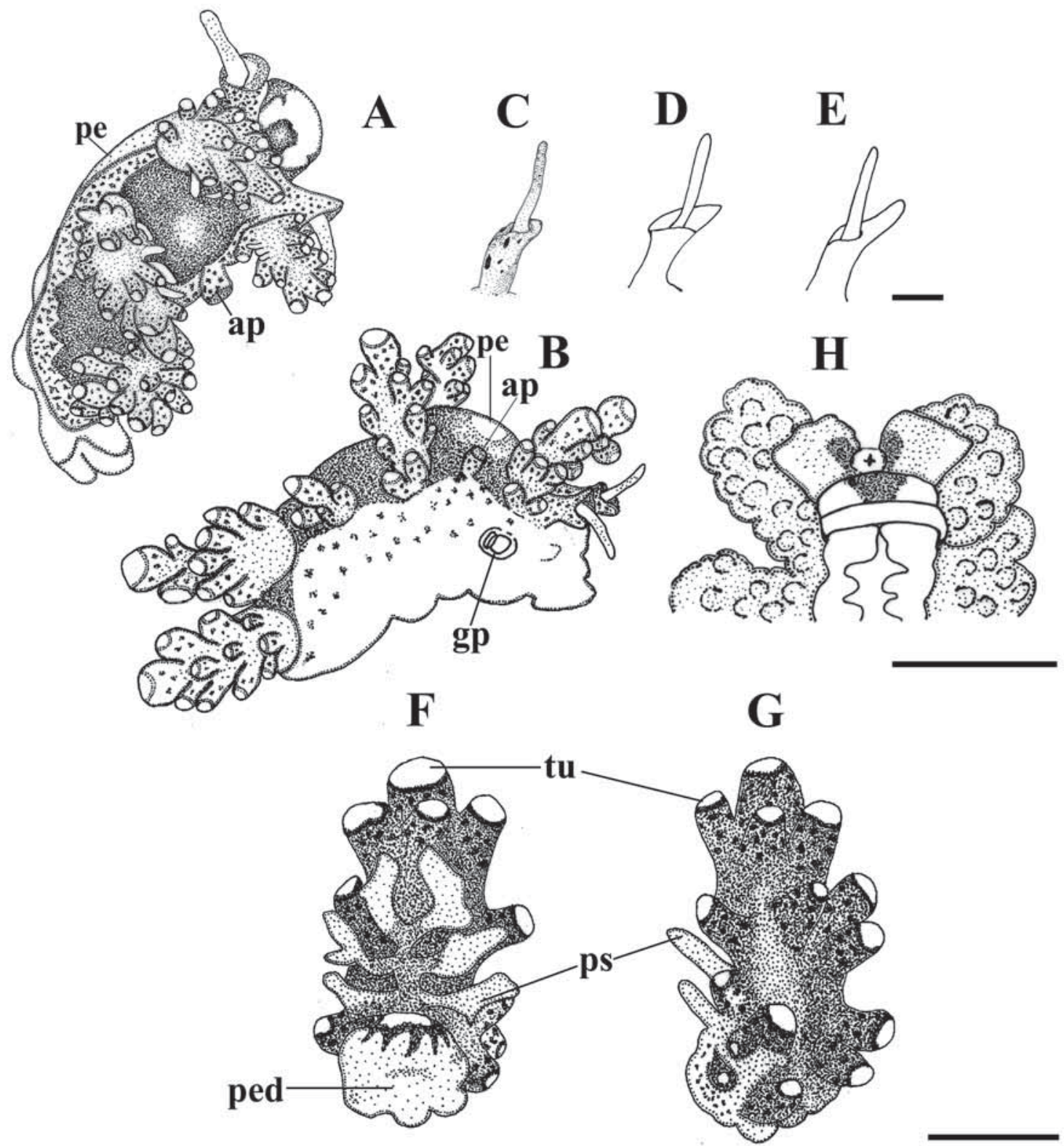

Fig. 2. Preserved specimen of D. uva Marcus, 1955 from the Chilean coast, length $5.4 \mathrm{~mm}$. A: Dorsal view of the body. B: Lateral view of the body. C, D, E: Various shapes of a rhinophoral sheath observed in various specimens. F: Ceras, interior view. G: Ceras, exterior view. H: Anterior-ventral view of the body. ap, anal papilla; gp, genital papilla; pe, perineurium; ped, peduncle; ps, pseudobranchia; tu, tubercle. Scale bars: A, B, H: $2 \mathrm{~mm}, \mathrm{C}, \mathrm{D}, \mathrm{E}: 1 \mathrm{~mm}, \mathrm{~F}, \mathrm{G}: 0.5 \mathrm{~mm}$.

bulb with its muscular, unarmed penis. The female part starts with a valve situated at the beginning of the oviduct that contacts the voluminous, piriform seminal receptacle and also the mucous gland. The very long vagina forms a U-shaped loop close to the upper part of the penial bulb. The vaginal duct becomes bulbous near its connection with the seminal receptacle, which is controlled by a small sphincter.
The female gland consists of three parts: the large mucous gland, the medium-sized capsule gland and the small membrane gland.

Histology (Figs 6, 7). The ovotestis consists of numerous acini. Generally, 5-6 globular, female acini surround one large, globular, male acinus. The hermaphroditic duct and the ampulla are lined by a thin and strongly ciliated epithelium. The ampulla 
A

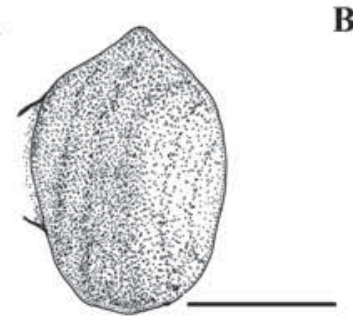

B

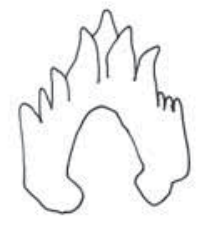

C

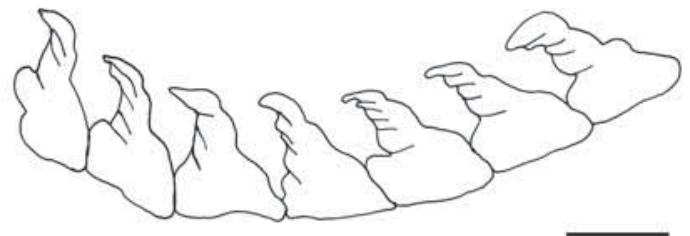

Fig. 3. A: Right jaw, dorsal view. B: Rachidian tooth. C: Radular teeth, lateral view. Scale bars: A: $1 \mathrm{~mm}, \mathrm{~B}, \mathrm{C}: 10 \mu \mathrm{m}$.

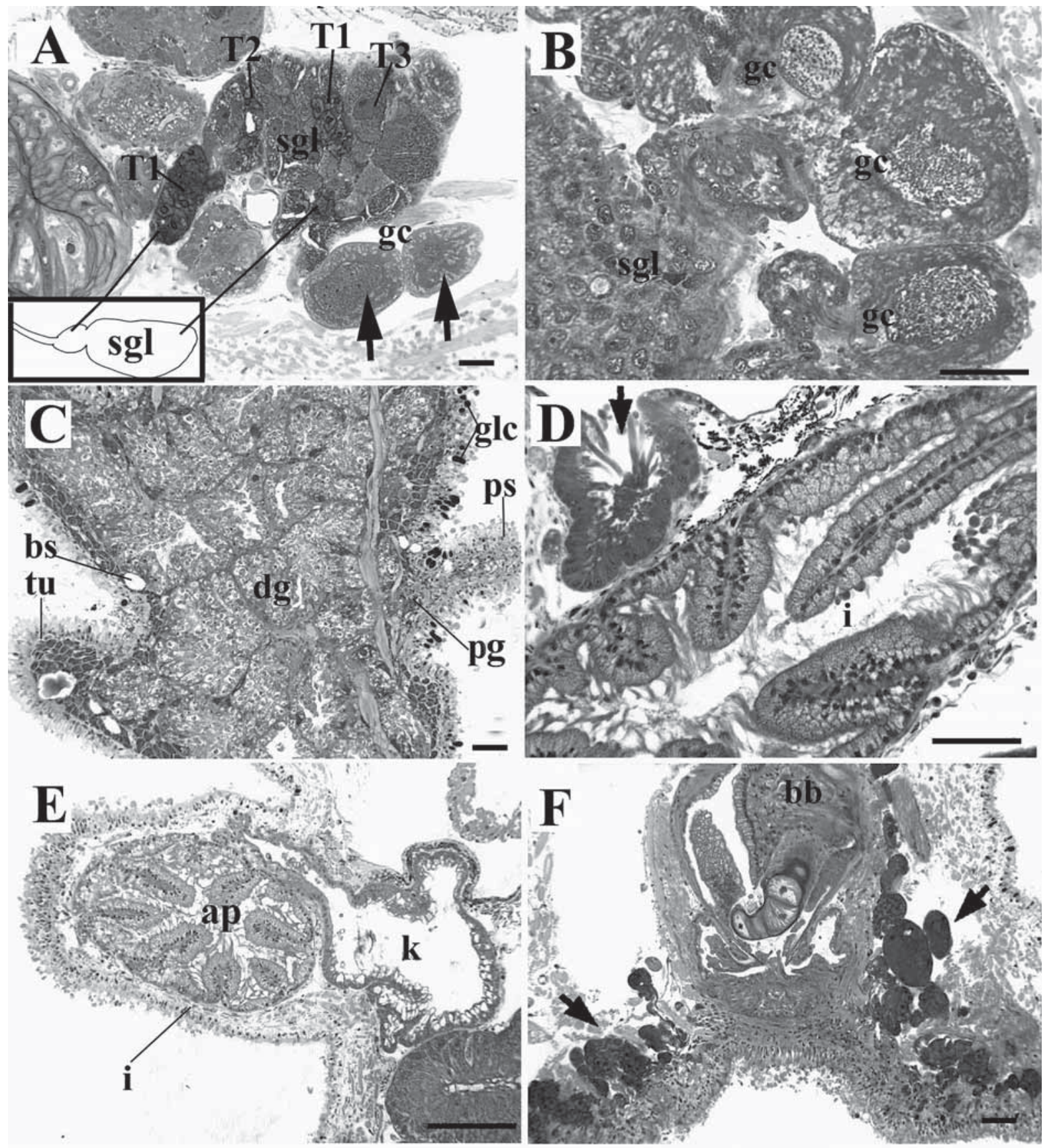


lumen is filled with spermatocytes (Fig. 6A). The prostate gland consists of two parts. The distal part has ciliated cells of a globular shape and varying height (Fig. 6B). Their nucleus is violet and located in basal position whereas the curved cell apex faces the lumen. The proximal part of the prostate shows highly columnar cells filled with granules, and a darkish violet nucleus in basal position (Fig. 6C). Together with these cells, small, triangular, ciliated epithelial cells are present. The ciliated epithelium of the vas deferens is surrounded by muscular layers. The muscular penial bulb is very well developed and the penis is smooth (Fig. 6D).

The ciliated vaginal epithelium consists of cubical and elongate cells with a central nucleus and a vacuolated cytoplasm (Fig. 7A). The seminal receptacle shows six lobes, each of which is studded with allosperm, with the sperm heads oriented towards the epithelial wall and the tails towards the lumen (Fig. 7A, B). A long, ciliated duct emerges from the receptacle, two small valves separate the oviduct from the spermoviduct (Fig. 7C). The capsule gland (Fig. 7D) has columnar secretory cells with a basal nucleus and a granulated cytoplasm with deep-blue secretory droplets. In between these cells, small, ciliated supporting cells occur that are very narrow at the base but taper towards the apex. The membrane gland (Fig. 7E) has roundish cells with a large, basal nucleus and large, pale-rose secretory droplets. These cells occur together with small, ciliated cells that are broad at the base and taper towards the lumen. Their small nucleus stains deep-blue. The mucous gland appears blue to fuchsia-stained and reveals an epithelium with two cell types, namely columnar secretory cells with a granulated cytoplasm and a small nucleus in a basal position, and ciliated cells with a small nucleus (Fig. 7F).

Fig. 4. A: Salivary gland (sgl), T1 cells of the distal part, T1, T2 and T3 cells of the proximal part, small, medium and large. respectively (see for the explanation the text) and giant cells (gc) around the salivary gland, inset: scheme of the bilobed salivary gland. B: Detail of the giant cells around the salivary gland (sgl). C: Detail of the ceras, interior occupied by the digestive gland (dg). D: Syrinx (arrow) opening to the pericardium. E: Anal papilla (ap) and kidney epithelium around the lumen. F: Pedal gland cells (arrows) to each side of the buccal bulb (bb). bs, blood space; glc, glandular cells; i, intestine; k, kidney; pg, pigment; ps, pseudobranch; tu, tubercle. Scale bars: $50 \mu \mathrm{m}$.

\section{Central nervous system and sensory organs}

Anatomy. The CNS is situated near the intersection of the pharynx and the anterior part of the oesophagus, and forms a circumoesophageal ring (Fig. 8). A pair of very small buccal ganglia is located below the buccal mass. Close to the site of emergence of the rhinophores, there is a pair of small, pedunculate rhinophoral ganglia. The cerebral and pleural ganglia are fused to a pair of spheroid cerebropleural ganglia, which form the largest part of the CNS. They give rise to one main, paired nerve running towards the intestine (Fig. 8). The smaller paired pedal ganglia are located below the cerebropleural ganglia and the oesophagus. Three main nerves (Fig. 8) can be seen leaving these ganglia, all running into ventral direction.

The paired eyes are situated directly laterally from the cerebropleural ganglia, and are connected with the optic ganglia by the long optic nerves.

Histology. Ganglia are surrounded by a perineurium (Fig. 9A, B, E, F) that is formed by fibroblasts and contains some dispersed muscle cells. Neuronal perikarya are located in the ganglion peripheries, whereas axons run in the central neuropil. Many neuronal somata form axon bundles that leave the ganglia as commissures, connectives or nerves. The cerebropleural ganglia are interconnected by a thick cerebropleural commissure (Fig. 9A, B). In these ganglia we distinguish four categories of nerve cell bodies on the basis of their size: giant, large, medium-sized and small. The giant neurons were only observed in the cerebropleural ganglia. They measure ca. $70 \mu \mathrm{m}$ in diameter, are spheroid, and have a large, central, blue nucleus (Fig. 9C). The large nerve cells (diameter ca. $40 \mu \mathrm{m}$ ), have a flattened apex that faces the perineurium (Fig. 9D). Like the medium-sized (diameter ca. $25 \mu \mathrm{m}$ ) and small neurons (diameter ca. $15 \mu \mathrm{m}$ ) they are present in all ganglia of the CNS. Many cells can be individually identified on the basis of their size, shape and their position in a ganglion, in each specimen studied.

The eyes are ovoid and have a largest diameter of ca. $60 \mu \mathrm{m}$. Their large, sea-blue-staining lens has a largest diameter of about $35 \mu \mathrm{m}$. The melanin at the inner face of the retina appears as small, deep-brown dots (Fig. 9E).

The paired statocysts are situated between the cerebropleural and pedal ganglia and reveal several otoconia in their lumen (Fig. 9F). 
A

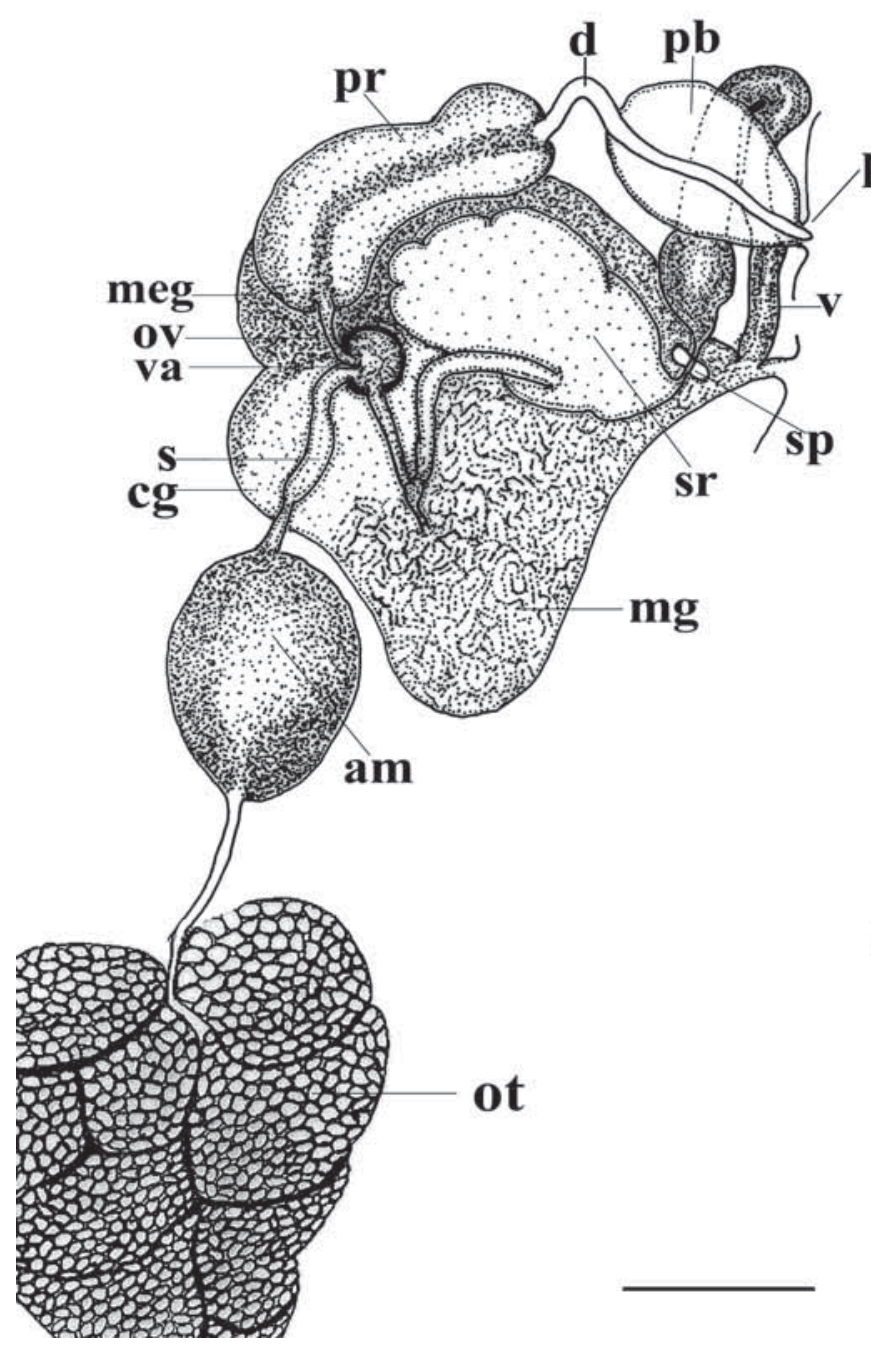

B
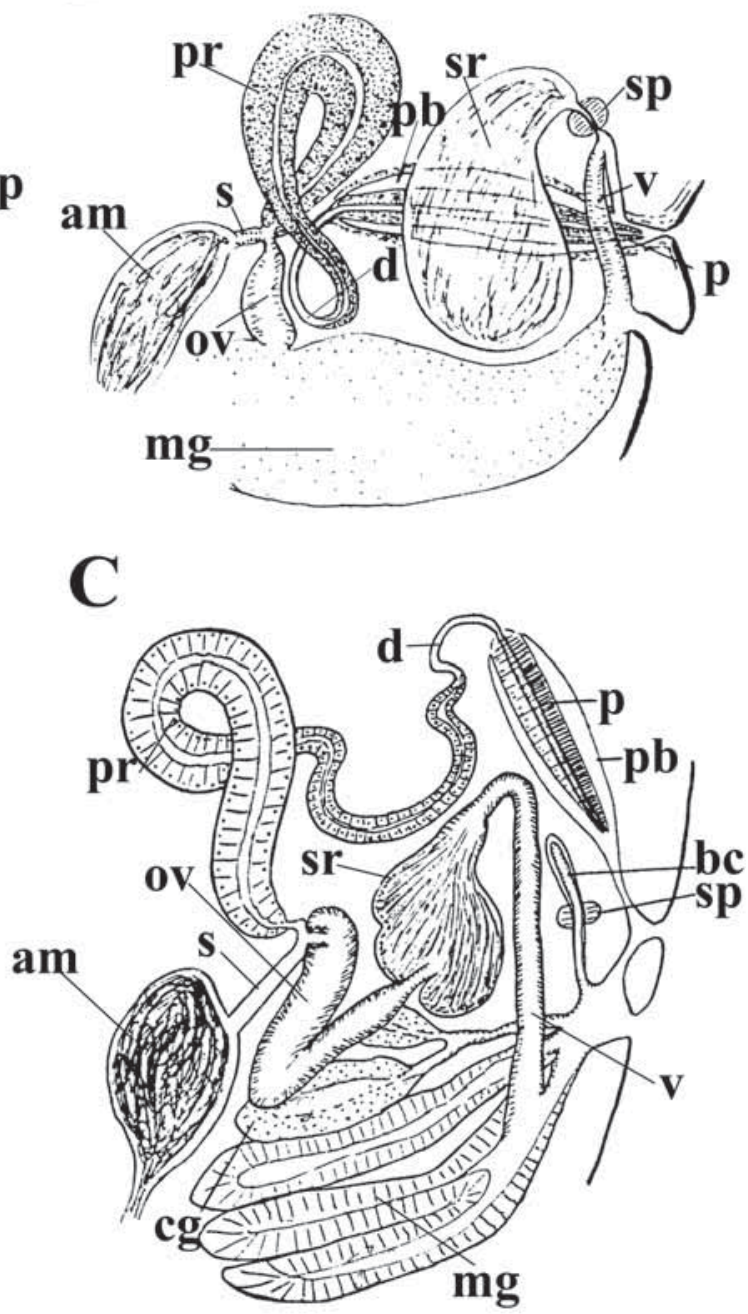

Fig. 5. Scheme of the reproductive system. A. Present study. B. According to Marcus (1957). C. According to Marcus (1959). am, ampulla; bc, bursa copulatrix; cg, capsule gland; d, vas deferens; meg, membrane gland; mg, mucous gland; ot, ovotestis; ov, oviduct; p, penis, pb, penial bulb; pr, prostate; s, spermoviduct; sp, sphincter; sr, seminal receptacle; v, vagina; va, valve. Scale bar: 0.5 mm.

\section{Egg mass}

The light-cream coloured egg mass is a thin, undulating ribbon of about $5 \mathrm{~mm}$ length (Fig. 10A). It is filled with numerous tiny, oval, encapsulated eggs, each with a mean diameter of about $90 \mu \mathrm{m}$. The egg mass is deposited over hydroid and bryozoan colonies. After collecting an egg mass, eggs continued to develop, with one embryo per capsule (Fig. 10B).

\section{Discusson}

In this study we described in detail the anatomy, morphology and histology of the nudibranch, D. uva from the Chilean coast. The description clearly reveals all the diagnostic characters of the genus Doto, i.e., with respect to the body and foot shape, cerata, rhinophores, position of the anus and nephroproct, frontal veil, masticatory border, teeth, and penis (Thompson and Brown, 1984; for listing see Intro- 


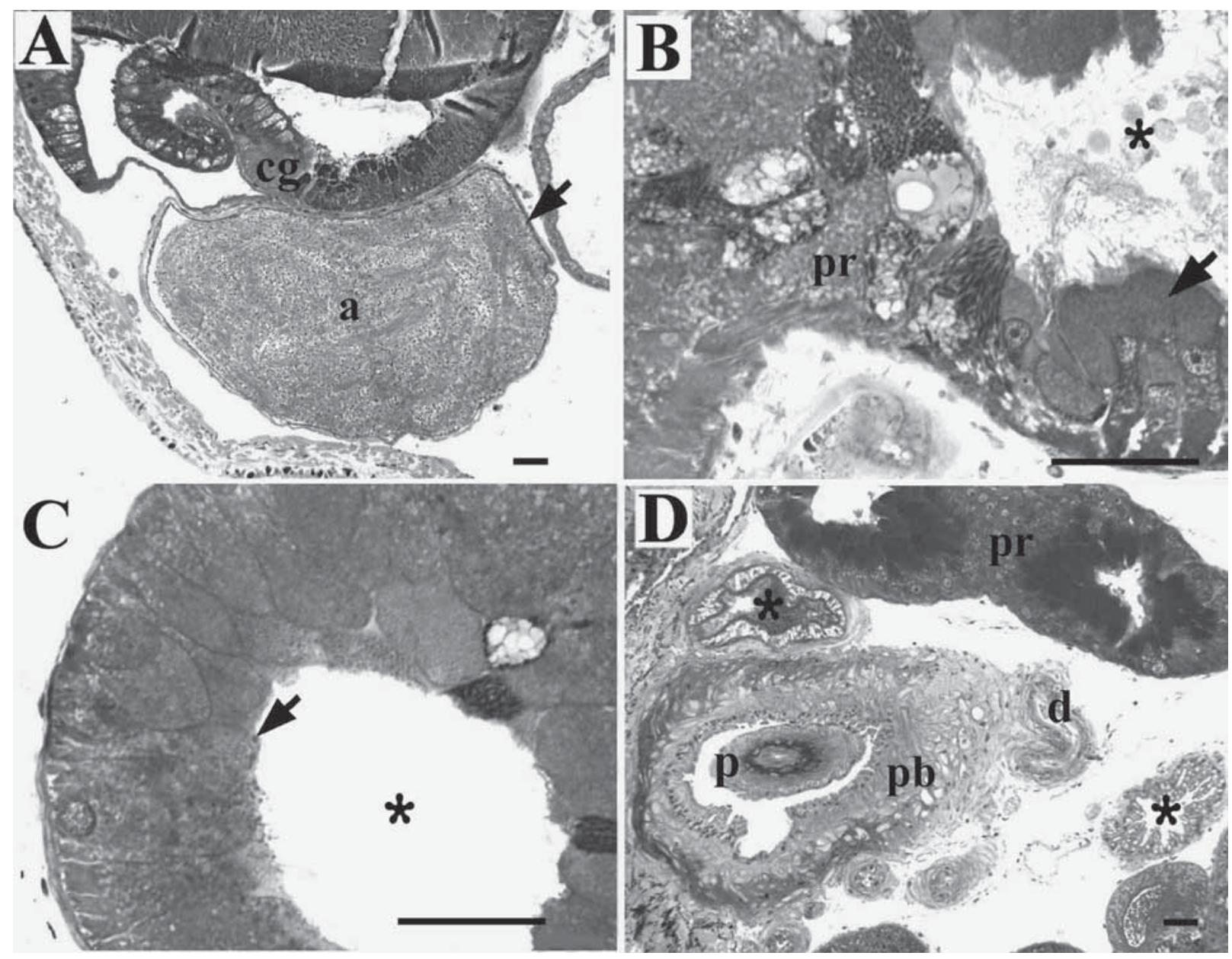

Fig. 6. Histology of reproductive system. A: Ampulla (a). B: Prostate (pr) with globular cells (arrow) around the lumen (asterisk). C: Epithelium of the prostate with columnar cells (arrow) around the lumen (asterisk). D: Penial bulb (pb), unarmed penis (p) and vagina (asterisk). cg, capsule gland; d, vas deferens. Scale bars: $40 \mu \mathrm{m}$.

duction). Each of these characters may not be unique for Doto uva, but it is the specific combination of these characters that separates Doto uva from other Doto species: a digestive system with bilobed salivary glands and a reproductive system characterized by (1) a voluminous ampulla, (2) a prostate gland consisting of two parts, (3) a short deferent duct, (4) an unarmed penis, (5) a seminal receptacle with internal lobes, (6) an oviduct with an internal valve, and (7) a vagina connected via a sphincter to the seminal receptacle.

Particular aspects of the characters typical for $D$. uva will be discussed below in a comparative context, as will new data on the animal's morphology, anatomy and histology. Finally, we will consider if
D. uva from the Chilean coast may be different from $D$. uva from the Brazilian coast as described by Marcus $(1955,1957)$.

\section{Doto uva from the Chilean coast}

The peculiar globular shape of the voluminous salivary gland of $D$. uva, with large cells surrounding the gland, seems to be similar to that described for other Doto species, namely D. coronata (Gmelin, 1791) by Hecht (1896) and Brygider (1914), D. pinnatifida (Montagu, 1804) by Hecht (1896) and, more recently, $D$. varians MacFarland, 1966 by MacFarland (1966), which is synonymous with $D$. kya Marcus, 1961 (McDonald, 1983). The giant 

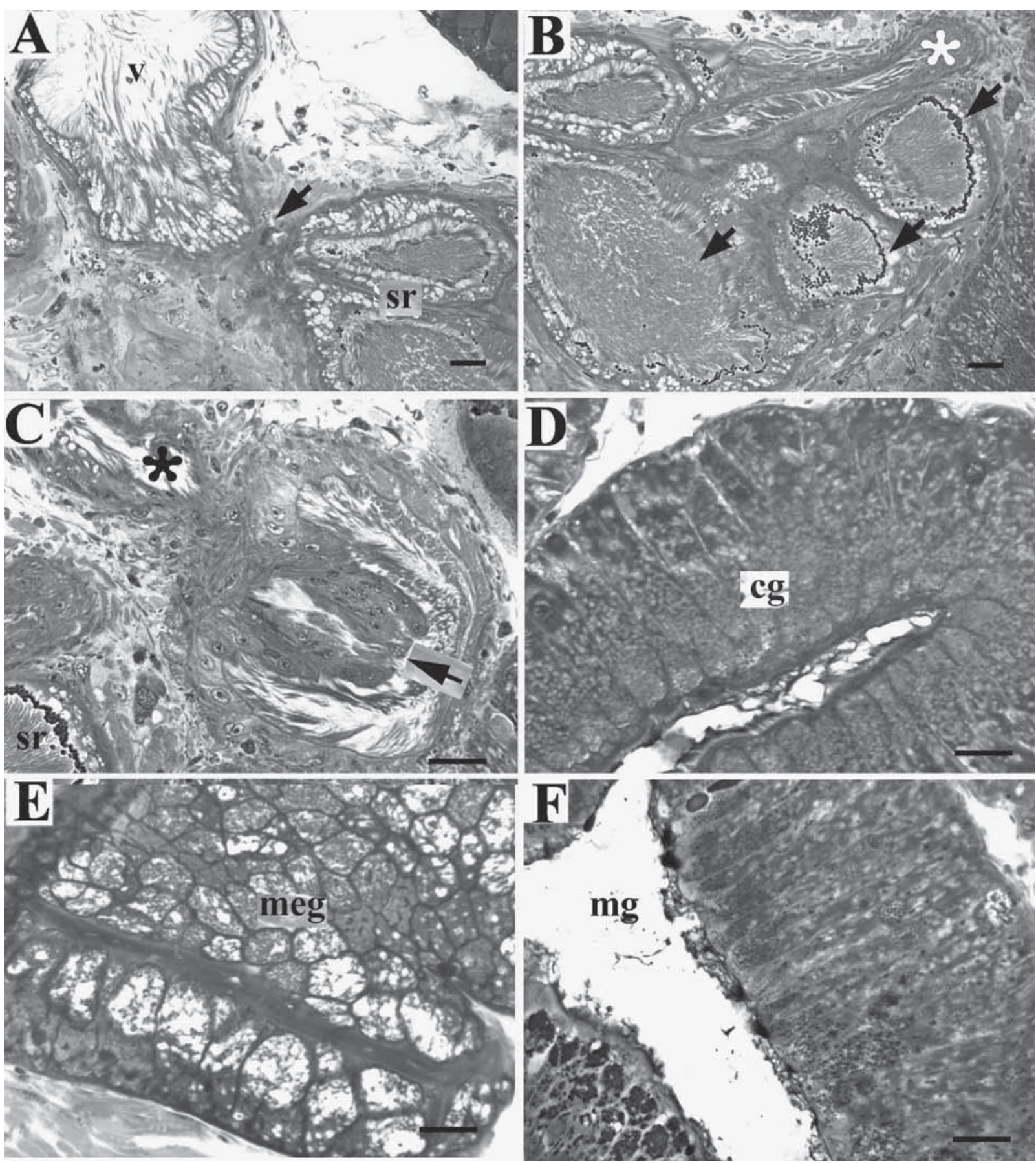

Fig. 7. Histology of reproductive system. A: Sphincter (arrow) between vagina (v) and seminal receptacle (sr). B: Seminal receptacle (arrows indicate lobes with allosperm) and spermoviduct (asterisk). C: Spermoviduct (asterisk) with valve inside oviduct (arrow), and seminal receptacle (sr). D: Capsule gland (cg). E: Membrane gland (meg). F: Mucous gland (mg). Scale bars: $20 \mu \mathrm{m}$.

cells in D. uva are similar in diameter to those of D. varians (diameter about $150 \mu \mathrm{m}$ ), but larger than those described for $D$. coronata and $D$. pinnatifida.
The diversity of secretory cell types in salivary glands of molluscs is well-established (Boer et al., 1967; Moura et al., 2003) but the nature of the large 


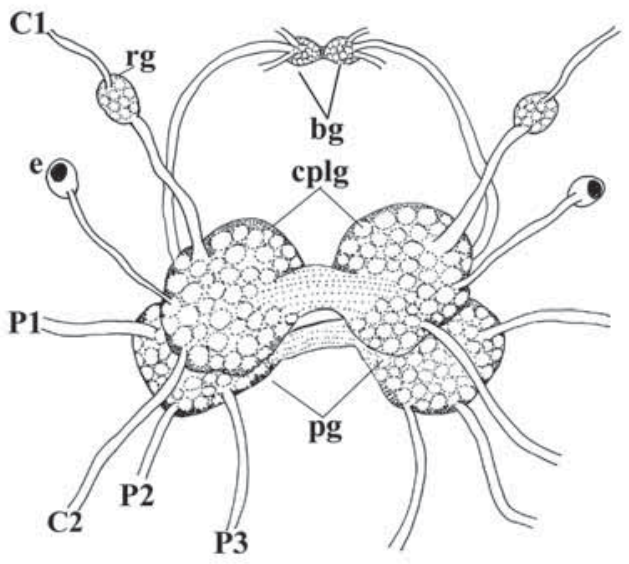

Fig. 8. Scheme of CNS. Nerves of cerebropleural ganglia (cplg) are denominated with a letter $\mathrm{C}$ and of pedal ganglia (pg) with a letter P. bg, buccal ganglia; $\mathrm{C}$ 1, rhinophoral nerve; $\mathrm{C} 2$, nerve running into the direction of the intestine; e, eye; P1, P2, P3, pedal nerves; rg, rhinophoral ganglion. Scale bar: $300 \mu \mathrm{m}$.

surrounding cells in D. uva is obscure. In view of the granulated appearance of the cytoplasm, the cells may have a secretory function. Possibly, they possess a high degree of polyploidy, as is common for large-sized cells in molluscs in general (see e.g. Boer et al., 1977).

Remarkably, Marcus (1957) reported that the Doto reproductive system lacks a seminal receptacle but has, instead, a voluminous bursa copulatrix (spermatheca) (Fig. 5B). Possibly, this description of a bursa is based on a misinterpretation, in view of the fact that also other Pacific and Atlantic Doto species lack a bursa copulatrix (O'Donoghue, 1921; Marcus, 1961), e.g. D. columbiana O'Donoghue, 1921, D. amyra Marcus, 1961 and D. kya. A similar arrangement of the reproductive system as found by us in D. uva, was reported for D. columbiana which also reveals a long vaginal duct. However, a difference is that in D. columbiana the sphincter is situated where the vagina opens into the female gland, and not near the connection site of the vagina with the seminal receptacle, as in our specimens.

Our study agrees with that of Marcus (1959) in that the reproductive system of $D$. uva from the Chilean coast contains one, very large and piriform seminal receptacle, but our specimens lack a bursa copulatrix whereas Marcus (1959) described a small one. However, as our serial section study strongly suggests, the structure Marcus described as bursa copulatrix most likely is the first part of the vaginal loop (Fig. 5A, C).

Taking the description of Marcus (1961) into account, Schrödl (2003) has suggested that D. uva and D. kya are closely related. Like D. uva, D. kya occurs at the Pacific coast, but should be restricted to North-America, living from Vancouver Island to California (Behrens, 1991). In the present study we observed several differences between the two species, e.g. with regard to body coloration pattern, the absence of dark rings on the cerata in D. kya, and the strongly ramifying pseudobranchs that hardly extend outside the cerata of D. uva (Marcus, 1961; MacFarland, 1966). Furthermore, the reproductive system of $D$. kya contains a shorter vaginal duct and a longer vas deferens than that of $D$. uva. Therefore, we consider D. uva and D. kya as distinct species.

The other two species of Doto known from the Brazilian coast, D. pita Marcus, 1955 and D. caramella Marcus, 1957, are clearly different from $D$. uva in the pattern of coloration, shape and distribution of the cerata, tubercles, and shape of their teeth (Marcus, 1955, 1957, 1961).

This is the first detailed report on the anatomy and histology of the CNS of D. uva. We have distinguished four types of nerve cells on the basis of cell body size. These size differences may reflect different degrees of polyploidy that have been shown to be related to the amount of DNA content in the nuclei of nerve cells of pulmonate gastropods (Boer et al., 1977). Obviously, this distinction is rather artificial as the functional diversity of neurons in the molluscan CNS is much higher than might be deduced from the presence of only four neuronal size classes. However, the distinction is functional in that it might form a basis to compare homologous neuron types between different nudibranchs and molluscan species in general. For instance, because of their position and flattened apical shape, the large nerve cells in the cerebropleural ganglia of $D$. uva may be homologous with the large neurosecretory growth hormone-producing cells in the cerebral ganglia of pulmonates (Geraerts, 1976; Roubos and van de Ven, 1987).

Comparison of Doto uva from Chile with Doto uva from Brazil (Table 1)

D. uva was described for the first time at the Brazil- 


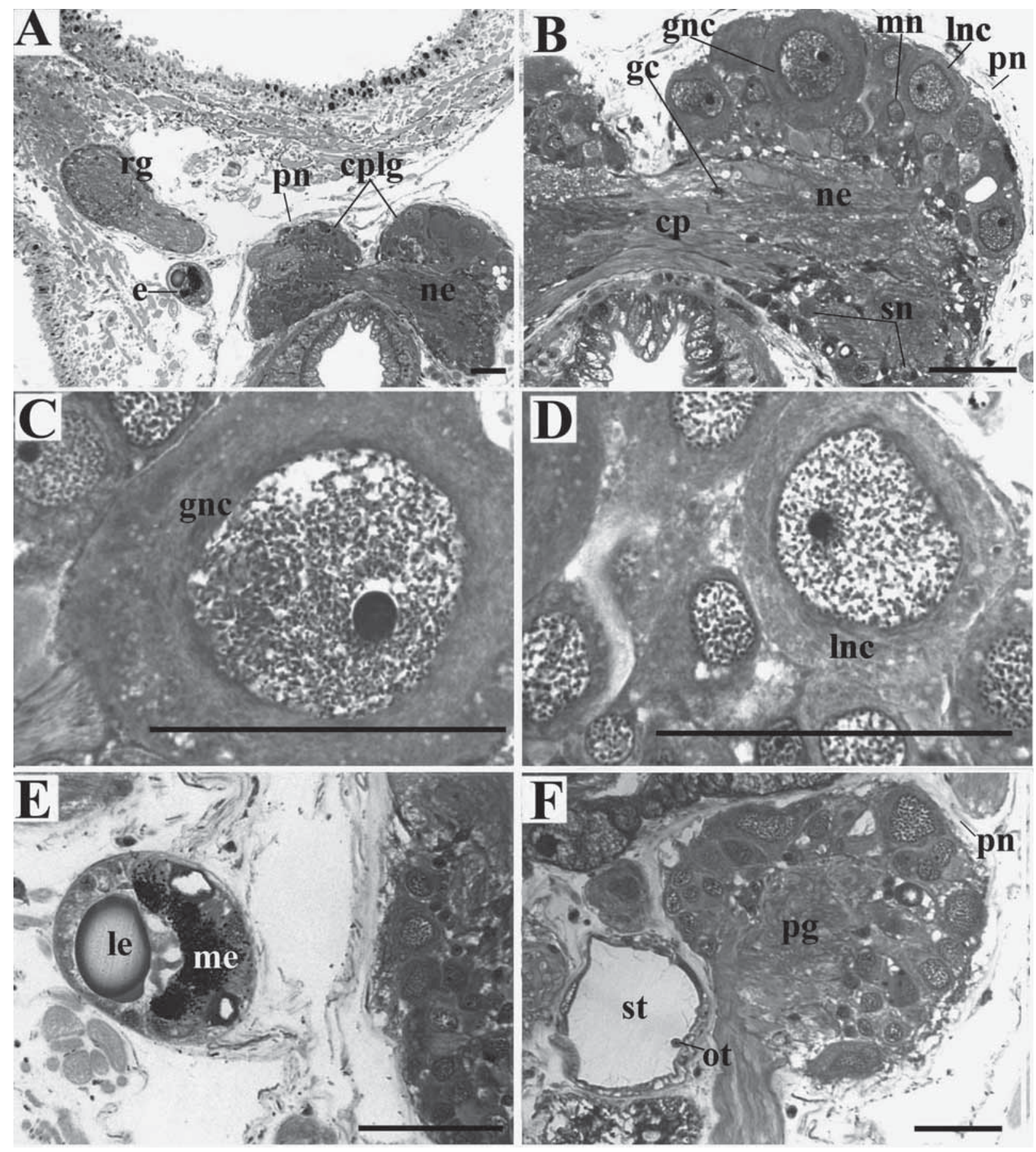

Fig. 9. CNS. A: Cerebropleural ganglia (cplg). B: Left cerebropleural ganglion (cp). C: Giant nerve cell (gnc) in right cerebropleural ganglion. D: Large nerve cell (lnc) in right pedal ganglion. E: Eye, with lens (le) and melanin (me). F. Statocyst (st) with small otoconium (ot), between left cerebropleural and pedal ganglion (pg). cp, cerebropleural connective; e, eye; gc, glial cell nucleus; mn, medium-sized neuron; ne, neuropil; pn, perineurium; rg, rhinophoral ganglion; sn, small neurons. Scale bars A-D: $50 \mu \mathrm{m}, \mathrm{E}, \mathrm{F}: 25 \mu \mathrm{m}$.

ian coast, by Marcus $(1955,1957)$. Later Marcus (1959) extended this description by studying $D$. $u v a$ at the coast of Chile, concluding that the speci- mens from both locations belong to the same species. The present data might challenge this conclusion, because our observations on the Chilean $D$. 

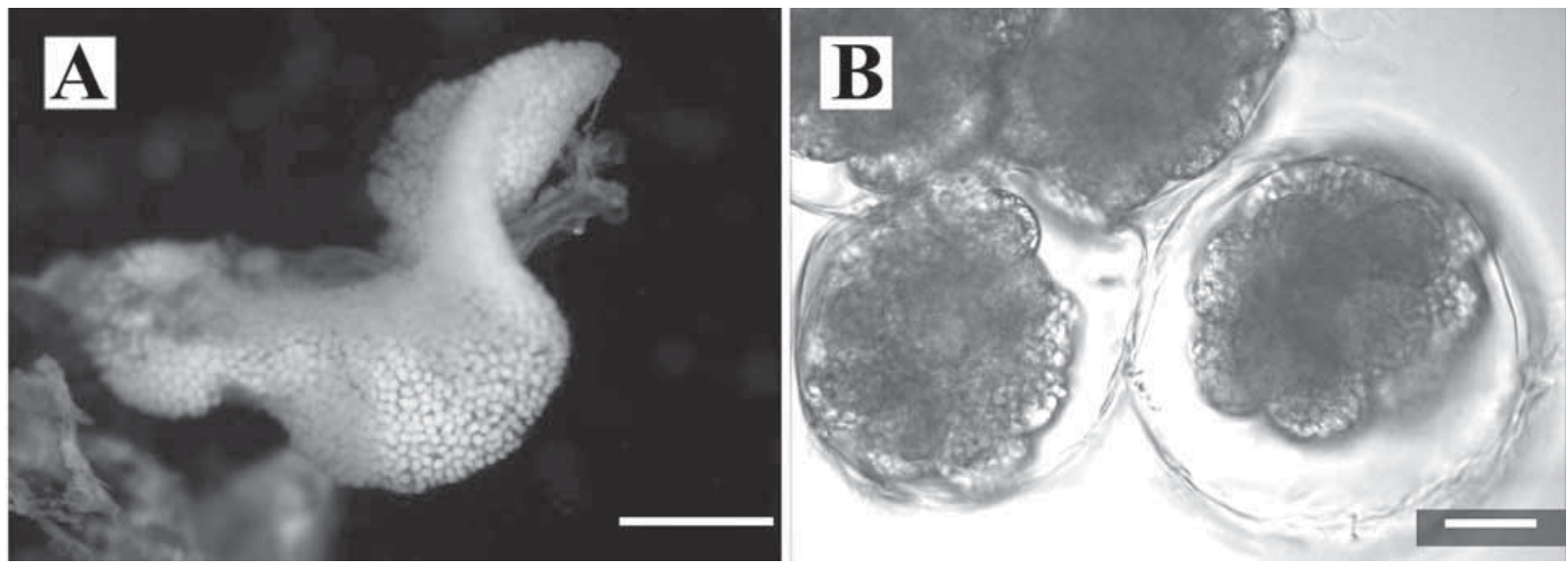

Fig. 10. A: Egg mass. B: Detail of egg mass with morula stages in egg capsule. Scale bar A: 1 mm, B: $20 \mu \mathrm{m}$.

uva and those of Marcus $(1955,1957)$ and more recently of ourselves on $D$. uva from the Brazilian coast, reveal large varieties in some characters among both specimens at both locations, raising the possibility two $D$. uva species occur mixed at both locations. In this respect, however, the following observations are relevant. First, irrespective of the location, it appears that the body coloration pattern of D. uva is white, yellow or pink, the spots dispersed over the body black or brown and the ramifications of the digestive gland pink, brown or grayish (Marcus, 1955, 1959; Schrödl, 1996; 2003; Schrödl et al., 2005; M.A. Fischer, unpublished results, present data; Table 1). Furthermore, cerata have either subapical dark-grey rings (Marcus, 1955, 1959), subapical black rings (present study) or basal black rings (Schrödl, 1996). Although these colour variations might be due to the existence of at least two species within a given population, it seems very likely that the differences are related to differences in individual developmental stage, feeding condition or to another physiological condition. A definite answer to this issue cannot be given as long as the biology of D. uva from the Pacific coast remains largely unknown.

Another source of variation within both the Chilean and Brazilian D. uva populations, is the number of radular teeth. We counted in two radula of $D$. uva from the Chilean coast, 61 and 63 teeth, which fits with Schrödl (2003), who counted 61-67 teeth in D. uva from Chile. Our specimens measured ca. 4.0 $\mathrm{mm}$ in preserved length, which is similar to the lengths of the specimens of $D$. uva investigated by
Schrödl (2003) (4.5 and $5 \mathrm{~mm}$ ). In contrast, Marcus $(1955,1957,1959)$ described that the radula of $D$. uva from both Brazil and Chile has as many as 86 teeth. The holotype studied by Marcus (1955) measured $2 \mathrm{~mm}$ in preserved length, but unfortunately, the lengths of the other specimens studied by Marcus $(1957,1959)$ have not been reported. Consequently, the precise relationship between radular teeth number and body length remains to be established and, therefore, this number cannot be used as a reliable parameter to distinguish different species of D. uva.

A third character of interest when considering the issue of species distinction, concerns the rachidian tooth. In our specimens this tooth is horseshoe-shaped, i.e., asymmetrical, with a central small cusp and 2-5 lateral denticles. However, Marcus $(1955,1959)$ described the rachidian tooth of D. uva from both Brazil and Chile to have only 2-3 lateral denticles whereas in his drawing of $D$. uva from Chile (Marcus, 1959) the tooth shows a central cusp with as many as 6 lateral denticles. Possibly, this variation in denticle number is related to the animal's age, but it could, again, also point to different species existing within each of the two localities.

The scheme of the reproductive system made by Marcus $(1957,1959)$ shows some remarkable differences with our scheme, mainly in the shape of the vagina and position of the sphincter (Fig. 5A-C) that we attributed to misinterpretation of the sequence of the serial histological sections.

Lemche (1976) has proposed morphological and 
Table 1. Comparison of characters and geographic distribution of Doto uva Marcus 1955 from the Chilean coast (present study) with other

\begin{tabular}{llll}
\hline References & Length $(\mathrm{mm})$ & Coloration & Cerata/row \\
\hline Marcus, 1955 & 4.5 A; 2.0 P & $\begin{array}{l}\text { White, transparent body with pale-orange internal organs; rose digestive gland; } \\
\text { white cerata; black spots on tubercles, body dorsum and head }\end{array}$ \\
\hline Marcus, 1957 & 8.0-9.0 A & One specimen with pale-rose body, another with pale-yellow body \\
\hline Marcus, 1959 & 4.0-6.5 P & $\begin{array}{l}\text { White body with dark spots on dorsum and one dark spot on the rhinophoral } \\
\text { sheath; dark rings in tubercles }\end{array}$ \\
\hline Schrödl, 1996 & until 8 A & White body with black spots; cerata with black rings on tubercle basis \\
\hline Schrödl, 2003 & until 8 P & Whitish body with black spots \\
\hline Present study & 5-9 A 3-6 P & $\begin{array}{l}\text { Yellow-hyaline body with brown spots on dorsum, head, lateral flanks, cerata, } \\
\text { anal papilla and rhinophoral sheath; digestive gland appears as dorsal, brown } \\
\text { or greyish band; tubercles with black ring; rhinophores with white small spots }\end{array}$
\end{tabular}

biological criteria to distinguish between European Doto species, e.g. rhinophorical sheath shape, food preference and shape of the egg mass. The rhinophore seems to be frontally tapered and more protruded in specimes from Brazil, but comparing the preserved specimens from Marcus (1957) and Marcus (1959) there is not a big difference in the rhinophorical shape (Fig. 1D, F, G). As long as data on food and egg masses are not available for the Brazilian Doto populations, these criteria cannot assist in solving the question as to the potential presence of two different species of D. uva from the South American coast.

Taken these arguments together, we propose to consider the Brazilian and Chilean populations of D. uva as belonging to the same species.

\section{Acknowledgements}

The authors wish to thank Mrs Elsa Gabriela Espinoza and Mr Ronaldo Rocco for assistance in collecting the material. We are also grateful to $\mathrm{Mr}$ Patricio Zabala (Pontificia Universidad Católica de Chile), Mr Anders Warén (Swedish Museum of Natural History) and Dr Luiz Ricardo Simone (Museu de Zoologia da Universidade de São Paulo) for making available specimens of $D$. uva. We also thank Dr Heike Wägele (University of Bonn, Germany) for providing laboratory facilities and advise, Dr Lucas Cervera Currado (University of Cádiz, Spain) for literature advise, Dr Elisabeth
Pierson (Radboud University Nijmegen) for technical assistance, and Dr Victoriano Urgorri (University Santiago de Compostela) for comments on the manuscript.

\section{References}

Baba K. 1938. Opisthobranchia of Kii, middle Japan. Journal of the Department of Agriculture, Kyushu Imperial University, 6: 1-19.

Baba K. 1949. Opisthobranchia of Sagami Bay collected by His Majesty The Emperor of Japan. 194 pp., 50 pls. Iwanami Shoten, Tokyo.

Baba K. 1955. Opisthobranch fauna in the vicinity of the Sado Marine Biological station, Sado Island, Japan Sea side. Collecting and Breeding [Saishu to Shiiku], 17: 165-168.

Baba K. 1971. Anatomical studies on three species of Doto (D. bella, D. japonica, and D. pita) from Japan (Nudibranchia: Dendronotoidea: Dotidae. Publications of the Seto Marine Biological Laboratory, 19: 73-79, Pls 4, 5.

Behrens DW. 1991. Pacific coast nudibranchs. Sea Challengers, Monterey, California.

Boer HH, Wendelaar Bonga SE, Rooijen N van. 1967. Light and electron microscopical investigations on the salivary glands of Lymnaea stagnalis (L.). Zeitschrift für Zellforschung, 76: 228-247.

Boer HH, Groot C, Jong-Brink M de, Cornelisse CJ. 1977. Polyploidy in the freshwater snail Lymnaea stagnalis (Gastropoda, Pulmonata). A cytophotometric analysis of the DNA in neurons and some other cell types. Netherlands Journal of Zoology, 27: 245-252.

Brygider W. 1914. Über den mikroskopischen Bau der Speichseldrusen bei den Nudibranchiata. Zeitschrift fur Wissenschaftliche Zoologie, 110: 359-418, pls. 12-14.

Farmer WM. 1980. Swimming gastropods (Opisthobranchia and Prosobranchia). The Veliger, 13: 73-89. 
specimens of Doto uva. A, alive; P, preserved; -, not studied.

\begin{tabular}{|c|c|c|c|c|}
\hline Radula & Rachidean tooth & Vagina & Seminal receptacle & Geographic distribution \\
\hline $86 \times(0.1 .0)$ & $\begin{array}{l}\text { Central cusp and } \\
\text { 2-3 lateral denticles }\end{array}$ & - & - & $\begin{array}{l}\text { Sao Sebastiao Island, } \\
\text { Sao Paulo, Brazil }\end{array}$ \\
\hline $86 \times(0.1 .0)$ & $\begin{array}{l}- \\
- \\
-\end{array}$ & $\begin{array}{l}\text { Short, wide and } \\
\text { muscular }\end{array}$ & $\begin{array}{l}\text { Large and piriform, } \\
\text { described asspermath }\end{array}$ & $\begin{array}{l}\text { Ilhabela and Sao Paulo, Brazil } \\
\text { ca }\end{array}$ \\
\hline $86 \times(0.1 .0)$ & $\begin{array}{l}\text { Central cusp and } \\
\text { 2-3 lateral denticles }\end{array}$ & Short; bursa type & Large and piriform & $\begin{array}{l}\text { Golf Ancud, Chile } \\
\left(41^{\circ} 46^{\prime} 30^{\prime} \mathrm{S} ; 73^{\circ} 06^{\prime} 45^{\prime \prime} \mathrm{W}\right)\end{array}$ \\
\hline - & (5 & - & - & Coliumo Bay, Chile $\left(36^{\circ} 32^{\prime} \mathrm{S} ; 7^{\circ} 57^{\prime} \mathrm{W}\right)$ \\
\hline $61-67 \times(0.1 .0)$ & $\begin{array}{l}\text { Central cusp and } \\
\text { 2-5 lateral denticles }\end{array}$ & - & $\begin{array}{l}\text { Stalked allosperm } \\
\text { receptacle }\end{array}$ & Coliumo Bay, Chile \\
\hline $61-63 \times(0.1 .0)$ & $\begin{array}{l}\text { Central cusp and } \\
\text { 2-5 lateral denticles }\end{array}$ & $\begin{array}{l}\text { Long; loop at the } \\
\text { upper part of penial } \\
\text { bulb. Bulbous close } \\
\text { to seminal receptacle }\end{array}$ & $\begin{array}{l}\text { Large and piriform } \\
\text { with internal lobes }\end{array}$ & $\begin{array}{l}\text { Punta Blanca, Tocopilla, Chile } \\
\left(22^{\circ} 04^{\prime} \mathrm{S} ; 70^{\circ} 12^{\prime} \mathrm{W}\right) \text {; La Herradura, } \\
\text { Chile }\left(29^{\circ} 58^{\prime} \mathrm{S} ; 71^{\circ} 22^{\prime} \mathrm{W}\right) \text {; Tongoy, } \\
\left(30^{\circ} 15^{\prime} \mathrm{S} ; 71^{\circ} 30^{\prime} \mathrm{W}\right)\end{array}$ \\
\hline
\end{tabular}

Fischer MA, Cervera JL. 2005. Checklist of the opisthobranchs (Mollusca: Gastropoda) from the Chilean coast deposited at the "Colección de Flora y Fauna Profesor Patricio Sanchez Reyes, Pontificia Universidad Católica de Chile”. Iberus, 23: 1-16.

Geraerts WPM. 1976. Control of growth by the neurosecretory hormone of the light green cells in the freshwater snail Lymnaea stagnalis. General and Comparative Endocrinology, 29: 61-71.

Gosliner TM, Williams GC. 1970. The opisthobranch mollusks of Marin county, California. The Veliger, 13: 175-180.

Hecht E. 1896. Contribution á l'étude des nudibranches. Mémoires de la Société Zoologique de France, 8: 539-711, pls. 1-5.

Lemche HM. 1976. New British species of Doto Oken, 1815 (Mollusca: Opisthobranchia). Journal of the Marine Biological Association of the United Kingdom, 56: 691-706.

MacFarland F. 1966. Studies of opisthobranchiate mollusks of the Pacific coast of North America. Memoirs of the Californian Academy of Science, 6: 1-545.

Marcus Er. 1955. Opisthobranchia from Brazil. Boletimda Faculdade de Filosofia, Ciencias e Letras, Universidade de Sao Paulo. Zoologia, 20: 89-200.

Marcus Er. 1957. On Opisthobranchia from Brazil (II). Journal of the Linnean Society Zoology, 43: 390-486.

Marcus Er. 1959. Lamellariacea und Opisthobranchia. Reports of the Lund University Chile expedition 1948-1949, Vol. 36. The Lunds Universitets. Arsskrift. N. F., 55: 69-71.

Marcus Er. 1961. Opisthobranch mollusks from California. The Veliger (Suppl.), 3: 1-856.

Marcus Ev, Marcus Er. 1963. Opisthobranchs from the Lesser Antilles. Studies on the Fauna of Curaçao and other Caribbean Islands, 19: 1-76.

Marcus Ev, Marcus Er. 1967. American opisthobranch molluscs Part I, Tropical American opisthobranchs, Part II, Opisthobranchs from the Gulf of California. Studies in Tropical Oceanography, Miami, 6: 1-256.
McDonald GR. 1983. A review of the nudibranchs of the California coast. Malacologia, 24: 114-276.

Moura KRS, Terra WR, Ribeiro AF. 2003. The functional organization of the salivary gland of Biomphalaria straminea (Gastropoda: Planorbidae): secretory mechanisms and enzymatic determinations. Journal of Molluscan Studies, 70: 21-29.

O’Donoghue CH. 1921. Nudibranchiate Mollusca from the Vancouver Island region. Transactions of the Royal Canadian Institute, 13: 147-209.

Odhner NH. 1936. Nudibranchia Dendronotacea. A revision of the system. Mémoires du Musée Royal d'Histoire Naturelle de Belgique, 2: 1057-1128.

Roubos EW, Ven AMH van de. 1987. Morphology of neurosecretory cells in basommatophoran snails homologous with egg-laying and growth hormone-producing cells of Lymnaea stagnalis. General and Comparative Endocrinology, 67: 7-23.

Schmekel RL, Portmann A. 1982. Opisthobranchia des Mittelmeeres. Nudibranchia und Sacoglossa. Berlin-New York: Springer Verlag. 410 pp., pls. 1-36

Schrödl M. 1996. Nudibranchia y Sacoglossa de Chile: Morfología exterior y distribución. Gayana Zoologica, 60: 17-62.

Schrödl M. 2003. Sea slugs of Southern South America. Conch Books, Hackenheim.

Schrödl M, Alarcón M, Bedriñana MA, Bravo LR, Bustamante CM, Carvalho R, Försterra R, Gallardo G, Häusserman CV, Salmen A. 2005. Nudipleura (Gastropoda, Opisthobranchia) from the southern Chilean Comau Fjord, with redescription of Polycera priva Er. Marcus, 1959. Vita Malacologica, 3: 23-33.

Thompson TE, Brown G. 1984. Biology of Opisthobranch Molluscs. 2. The Ray Society, publication 156. London: 1-229.

Received: 3 February 2006

Accepted: 28 June 2006 
